\title{
Evolution of damage control surgery in non- traumatic abdominal pathology: a light in the darkness
}

\section{Evolución de la cirugía de control de daños en patología no traumática abdominal: un faro en medio de la tormenta}

OPEN ACCESS

Citation: Ordoñez CA, Caicedo Y, Parra MW, Rodríguez-Holguín F, Serna JJ, Salcedo A, Franco MJ, Toro LE, Pino LF, Guzmán-Rodríguez M, Orlas C, Herrera-Escobar JP, GonzálezHadad A, Alain HM, Aristizabal G, García A.Evolución de la cirugía de control de daños en patología no traumática abdominal: un faro en medio de la tormenta Colomb Méd (Cali), 2021; 52(2):e4194809

http://doi.org/10.25100/ cm.v52i2.4809

Received : 01 Apr 2021

Revised: 30 Apr 2021

Accepted : 07 Jun 2021

Published: 30 Jun 2021

Keywords:

Negative-pressure wound therapy, shock, hemorrhagic, critical illness, thoracic injuries, anastomosis, surgical, peritonitis, damage control surgery

Palabras clave:

Terapia de heridas con presión negativa, choque, hemorrágico, enfermedad crítica, lesiones torácicas, anastomosis quirúrgica, peritonitis, cirugía de control de daños.

\author{
Carlos A. Ordoñez, ${ }^{1,2,3}$ (Daset Caicedo, ${ }^{4}$ Michael W. Parra, ${ }^{5}$ Fernando Rodríguez- \\ Holguín, ${ }^{1}$ José Julián Serna, ${ }^{1,2,3,6}$ Alexander Salcedo, ${ }^{1,2,3,6}$ María Josefa Franco, ${ }^{1}$ \\ Luis Eduardo Toro, ${ }^{1}$ Luis Fernando Pino, ${ }^{2,6}$ Mónica Guzmán-Rodríguez, ${ }^{7}$ Claudia \\ Orlas, ${ }^{8}$ DJuan Pablo Herrera-Escobar, ${ }^{8}$ Adolfo González-Hadad, ${ }^{2,6,9}$ Mario Alain Herrera, ${ }^{2,6}$ \\ (D) Gonzalo Aristizábal, ${ }^{1}$ Alberto García ${ }^{1,2,3}$ \\ ordonezcarlosa@gmail.com,carlos.ordonez@fvl.org.co
}

1 Fundación Valle del Lili. Department of Surgery. Division of Trauma and Acute Care Surgery, Cali, Colombia., 2 Universidad del Valle, Facultad de Salud, Escuela de Medicina, Department of Surgery. Division of Trauma and Acute Care Surgery, Cali, Colombia., 3 Universidad Icesi, Cali, Colombia., 4 Fundación Valle del Lili, Centro de Investigaciones Clínicas (CIC), Cali, Colombia, 5 Broward General Level I Trauma Center, Department of Trauma Critical Care, Fort Lauderdale, FL - USA, 6 Hospital Universitario del Valle, Department of Surgery. Division of Trauma and Acute Care Surgery, Cali, Colombia., 7 Universidad de Chile, Facultad de Medicina,Instituto de Ciencias Biomédicas, Santiago de Chile, Chile., 8 Harvard Medical School \& Harvard T.H. Chan School of Public Health, Department of Surgery, Center for Surgery and Public Health, Brigham \& Women's Hospital, Boston - USA, 9 Centro Médico Imbanaco, Cali, Colombia.

\section{Abstract}

Damage control surgery is based on temporal control of the injury, physiologic recovery and posterior deferred definitive management. This strategy began in the 1980s and became a formal concept in 1993. It has proven to be a strategy that reduces mortality in severely injured trauma patients. Nevertheless, the concept of damage control in non-traumatic abdominal pathology remains controversial. This article aims to gather historical experiences in damage control surgery performed in non-traumatic abdominal emergency pathology patients and present a novel management algorithm. This strategy could be a surgical option to treat hemodynamically unstable patients in catastrophic scenarios such as hemorrhagic and septic shock caused by peritonitis, pancreatitis, acute mesenteric ischemia, among others. Therefore, damage control surgery is light amid better short- and long-term results. 
Copyright: @ $\odot 2021$ Universidad del Valle (c) (1) $(-)$

Conflicts of interest:

The authors declare that they have no conflict of interest.

Acknowledgments:

We acknowledge Isabella CaicedoHolguin for her contributions to the drafting of the manuscript.

Corresponding author:

Carlos A. Ordonez, MD, FACS. Division of Trauma and Acute Care Surgery, Department of Surgery. Fundación Valle del Lili. Cali, Colombia; Division of Trauma and Acute Care Surgery, Department of Surgery, Universidad del Valle, Cali, Colombia; Universidad Icesi, Cali, Colombia. Email: ordonezcarlosa@gmail.com, carlos.ordonez@fvl.org.co

\section{Resumen}

La cirugía de control de daños es una estrategia de control temporal del daño tisular y recuperación fisiológica para un manejo definitivo diferido. Esta estrategia tiene antecedentes en el mundo del trauma desde la década de 1980, hasta su formalización conceptual en 1993. Hasta el momento ha demostrado ser una estrategia factible y que reduce la mortalidad en los pacientes críticamente enfermos. Sin embargo, el manejo de patologías abdominales no traumáticas aun es tema de discusión sobre su factibilidad y seguridad. El presente articulo tiene como objetivo realizar un relato histórico y experiencias en la aplicación de la cirugía de control de daños en emergencias quirúrgicas abdominales no asociadas a trauma y presentar un algoritmo de manejo usando los principios de la cirugía de control de daños. La aplicabilidad del control de daños en no trauma se enfrenta a los contextos de shock hemorrágico y séptico para patologías como peritonitis generalizada, peritonitis postquirúrgica, pancreatitis, isquemia mesentérica aguda, entre otras. Se ha demostrado que el uso de control de daños representa una luz para el cirujano ante la tormenta de la incertidumbre de la descompensación metabólica en el manejo de emergencias abdominales, para crear un puente para su manejo definitivo y permitir anastomosis como estrategia de reconstrucción intestinal y mejorar los resultados a corto y largo plazo.

\section{Remark}

\section{1) Why was this study conducted?}

This article aims to gather historical experiences in damage control surgery performed in patients with non-traumatic abdominal emergency pathology and to present a novel management algorithm. This strategy could be a surgical option to treat hemodynamically unstable patients in catastrophic scenarios such as hemorrhagic and septic shock caused by peritonitis, pancreatitis, acute mesenteric ischemia, among others.

\section{2) What were the most relevant results of the study?}

We propose an algorithm that includes the principles of damage control surgery and deferred anastomosis as the main surgical strategy for intestinal reconstruction.

\section{3) What do these results contribute?}

The principles of damage control surgery can be applied in non-traumatic abdominal pathologies. This strategy is feasible and safe without increasing mortality or morbidity. It translates into a time window that allows a deferred intestinal reconstruction by anastomosis with better short- and long-term results. 


\section{Introduction}

Damage control surgery is based on temporal control of the injury, physiologic recovery and posterior deferred definitive management ${ }^{1}$. This strategy has been traditionally performed in patients with severe abdominal and/or thoracic trauma ${ }^{2,3}$. However, scenarios of hemodynamically unstable non-trauma patients with emergency pathologies treated with damage control surgery have been described but remain controversial in feasibility and safety ${ }^{4-6}$. Therefore, this article aims to gather historical experiences in damage control surgery performed in non-traumatic abdominal emergency pathology patients with the presentation of a novel management algorithm.

This article is a consensus that synthesizes the experience earned during the past 30 years in trauma management, general surgery, and critical care acquired by the Trauma and Emergency Surgery (CTE) group from Cali, Colombia which is made up of experts from the Hospital Universitario del Valle "Evaristo García", the Hospital Universitario Fundación Valle del Lili, the Universidad del Valle and Universidad Icesi, and the collaboration of national and international specialists from the Asociación Colombiana de Cirugía and the Pan-American Trauma Society.

\section{Historical evolution}

\section{Damage control in trauma: The basis of the lighthouse}

In the 1980s, the debate began about the use of temporary strategies for managing abdominal catastrophes such as severe liver or splenic trauma ${ }^{7-9}$. The first reports of abbreviated procedures showed reduced surgical time, lower postoperative complications, and higher survival rates ${ }^{10}$. In 1993, Rotondo and Schwab, based on a series of 22 patients with abdominal vascular trauma who underwent abbreviated procedures, proposed Damage Control Surgery ${ }^{11}$. This emerging evidence showing an increase in the survival rates of patients treated with damage control surgery triggered a surgical revolution ${ }^{12}$.

However, with the implementation of damage control surgery, new challenges associated with the temporary management of the injury arose. The deferred management of cavities such as the abdomen raised how to treat the abdominal wall ${ }^{13}$. A temporal closure strategy such as Bogotá bag (plastic covering of the cavity) was proposed ${ }^{1}$. Nevertheless, some patients managed with this technique presented persistent hemodynamic instability due to Abdominal Compartment Syndrome, which is defined as an increase in intraabdominal pressure above $12 \mathrm{mmHg}$ caused by intestinal edema secondary to mechanical abdominal organ contention. This represented a significant compromise in organ perfusion and ventilatory dynamics ${ }^{14-}$ ${ }^{16}$. Negative pressure wound therapy represented a solution to this challenge allowing a mechanical contention of the abdominal cavity, collection drainage, and injury hemostasis 3,17 .

The concept of Damage Control Surgery was extended beyond the operating room to include prehospital settings, emergency room, intensive care units, and a multidisciplinary team to treat severely injured trauma patients ${ }^{11}$. In 2007, Holcomb et al. proposed the concept of "Damage Control Resuscitation" that brings together damage control surgery with hemostatic resuscitation and permissive hypotension ${ }^{18,19}$. Recently, endovascular strategies such as REBOA placement and angioembolization have been proposed as the fourth pillar for damage control resuscitation ${ }^{20}$. This proposal is related to the new concept of "Endovascular Trauma Management-EVTM" which consists of the use of endovascular tools to treat severely injured trauma patients ${ }^{21}$.

\section{Damage control in non-traumatic abdominal emergencies: Building the lighthouse}

The evolution of damage control surgery for non-traumatic abdominal emergencies is rather initiating. Life-threatening non-traumatic pathologies include generalized peritonitis, acute mesenteric ischemia, pancreatitis, necrotizing enterocolitis, and/or aortic dissection ${ }^{22}$.

Two main pathophysiologic events that compromise the patient's life are a hemorrhagic 
and septic shock. Sepsis is an imbalance between anti-inflammatory and pro-inflammatory factors associated with an infectious process ${ }^{23}$. Damage control surgery allows rapid control of abdominal contamination, avoiding major tissue injury and/or late interventions, which translates into an early resuscitation and physiological recovery ${ }^{22}$.

In 2004, Finlay et al. performed the first study applying the principles of damage control surgery to non-traumatic pathology. They treated nine patients with intraabdominal sepsis secondary to hollow viscus perforation, three abdominal aortic aneurysms, one post-surgical hemorrhage, and one retroperitoneal hemorrhage with damage control surgery, showing a decrease in mortality compared with the predicted one ${ }^{24}$. In the same year, Banieghbal et al. (, ${ }^{24}$,performed a retrospective study in neonates with acute mesenteric ischemia who underwent damage control surgery. These interventions increase survival and reduce the need for ostomies and their complications.

Thus, damage control surgery has been proposed as an alternative in the emergency surgery scenario. Some considerations in damage control surgery in specific pathologies are discussed below.

Generalized peritonitis caused by gastrointestinal perforation. Abdominal sepsis causes a severe physiological compromise that represents a risk in anastomosis and anatomical reconstruction, with high anastomotic leak risk. Aggressive resuscitation, broad-spectrum antibiotics, and damage control surgery are the basis in abdominal contamination management in critically ill patients. Perathoner et al. presented an experience with 27 patients with acute perforated diverticulitis and peritonitis. Overall mortality was $26 \%$. Patients undergoing anastomosis were $70 \%$, with only one case of anastomosis dehiscence ${ }^{25}$. These results have been similar to those reported in other studies in which clinical outcomes such as postoperative complication rates, type of device for abdominal wall closure, and resuscitation efforts have been included. Analyses adjusted for these confounding variables estimate the effect of damage control surgery in patients with acute diverticulitis ${ }^{26-28}$.

Acute mesenteric ischemia. Acute mesenteric ischemia represents a surgical challenge due to its delayed diagnosis associated with greater hemodynamic compromise and a higher probability of death. Temporary control techniques of intestinal ischemia with endovascular approaches allow an abbreviated treatment with better clinical results. In 2009, Person et al. described a series of 31 patients who underwent damage control and of those, 10 had acute mesenteric ischemia. They reported higher mortality in the patients who underwent definite surgery. Nevertheless, hemodynamic compromise and multiorgan failure were greater in patients who underwent damage control surgery, representing a confusion factor ${ }^{29}$. Also, Subramanian et al. performed a study in patients older than 65 years old treated with damage control surgery; 14 patients had intestinal ischemia and underwent damage control celiotomy. They concluded that age is not a predictor of adverse outcomes ${ }^{30}$.

Duodenal bleeding or gastric ulcer. The general use of endoscopic approach and proton pump inhibitors has significantly reduced severe upper gastrointestinal bleeding. However, damage control surgery represents an alternative in cases where hemorrhagic control is not achieved despite these strategies. Khan et al. reported their experience with 42 patients undergoing damage control surgery with emergency non-traumatic abdominal pathology. Thirteen patients had gastrointestinal bleeding and complications such as intraabdominal collection and late abdominal sepsis. Additionally, they reported the effect of early abdominal wall closure after index surgery as a prognostic factor to avoid complications ${ }^{31}$.

Complicated pancreatic surgery. The accidental injury of the portal system or retrohepatic veins in pancreatic surgery is associated with higher mortality. A similar situation in necrotizing pancreatitis surgery could be presented where a vascular injury may be a lifethreatening hemorrhage. Thus, damage control techniques for vascular lesions associated with pancreatic disease allow bleeding control and subsequent physiological recovery ${ }^{32}$. 


\section{Damage Control Surgery for non-traumatic peritonitis: erecting the lighthouse light}

The indications for damage control surgery in non-traumatized patients are a matter of debate. Evidence indicates that the application of damage control surgery in patients with no severe physiological compromise could be non-beneficial ${ }^{22}$. Nevertheless, the impact of differed abdominal closure, surgical technique, intestinal repair type, and the comparison with conventional management is not defined. Our Trauma and Emergency Surgery group have studied these issues for the past 30 years in non-traumatic critically ill patients.

In 2006, Ordoñez and Puyana reported the first experience of the group describing the management of deferred intestinal repair by the following steps: contamination control, bowel in discontinuity, and delayed abdominal closure with negative pressure dressing ${ }^{33}$. With this first experience, we evaluate the impact of abbreviated relaparotomy in patients with nontraumatic peritonitis, finding that it was not associated with higher mortality ${ }^{34}$.

Then, the impact of the use of the intestinal reconstruction strategy through deferred anastomosis was evaluated. This intervention is an option in the management of this type of patient and avoids ostomies, improving postoperative quality of life ${ }^{35}$.

In 2010, a detailed analysis of the advantages of patients managed with abbreviated anastomosis vs. abbreviated ostomy was conducted. There were no significant differences regarding mortality and morbidity among groups. Therefore deferred anastomosis is a safe strategy after the control of septic foci ${ }^{36}$.

\section{Management of damage control in non-traumatic abdominal pathology: turning on the light during the storm}

Up to this point, a review has been made through the principles of damage control in trauma and the first experiences in non-traumatic pathologies. It is time to apply the principles of damage control for non-traumatic abdominal pathologies, which can lead to septic and hemorrhagic shock. This is the reason why damage control application phases must be recognized (Table 1 )

To meet these objectives and based on the experience over the last 15 years. In 2021, Ordoñez et al. published a comparative analysis of patients who underwent damage control surgery vs. definite surgery in the index surgery ${ }^{37}$. Damage control surgery is not associated with higher mortality, hospital length of stay, hemodynamic support requirements, or complication rates. Furthermore, the most commonly used repair technique in $85 \%$ of patients who underwent

Table 1. Damage Control Surgery in Non-traumatic Abdominal Pathology

\begin{tabular}{|c|c|c|}
\hline & Septic Shock & Hemorrhagic Shock \\
\hline \multirow[t]{4}{*}{ Phase 0 - Prehospital attention } & Early diagnosis & Early Diagnosis \\
\hline & Vasopressor and intravenous fluids & Hemostatic resuscitation without delaying surgery \\
\hline & Hypothermia correction & \\
\hline & Early broad-spectrum antibiotic administration & \\
\hline Phase I & $\begin{array}{l}\text { Identification of the source of infection and evaluation of } \\
\text { the clinical state }\end{array}$ & $\begin{array}{l}\text { Identification of bleeding source and evaluation of the } \\
\text { clinical state }\end{array}$ \\
\hline \multirow[t]{3}{*}{ Phase II } & Decontamination & Bleeding control \\
\hline & Infection source control & Differed abdominal wall closure \\
\hline & Differed abdominal wall closure & \\
\hline \multirow[t]{2}{*}{ Phase III } & $\begin{array}{l}\text { Intensive Care Unit resuscitation, acidosis, hypothermia, } \\
\text { and coagulopathy correction }\end{array}$ & $\begin{array}{l}\text { Intensive Care Unit physiologic resuscitation, acidosis, } \\
\text { hypothermia, and coagulopathy correction. }\end{array}$ \\
\hline & Antibiotic management according to resistance profile. & \\
\hline Phase IV & $\begin{array}{l}\text { Surgical reevaluation, definite repair, and abdominal wall } \\
\text { closure }\end{array}$ & $\begin{array}{l}\text { Surgical reevaluation, definite repair, and abdominal } \\
\text { wall closure }\end{array}$ \\
\hline
\end{tabular}




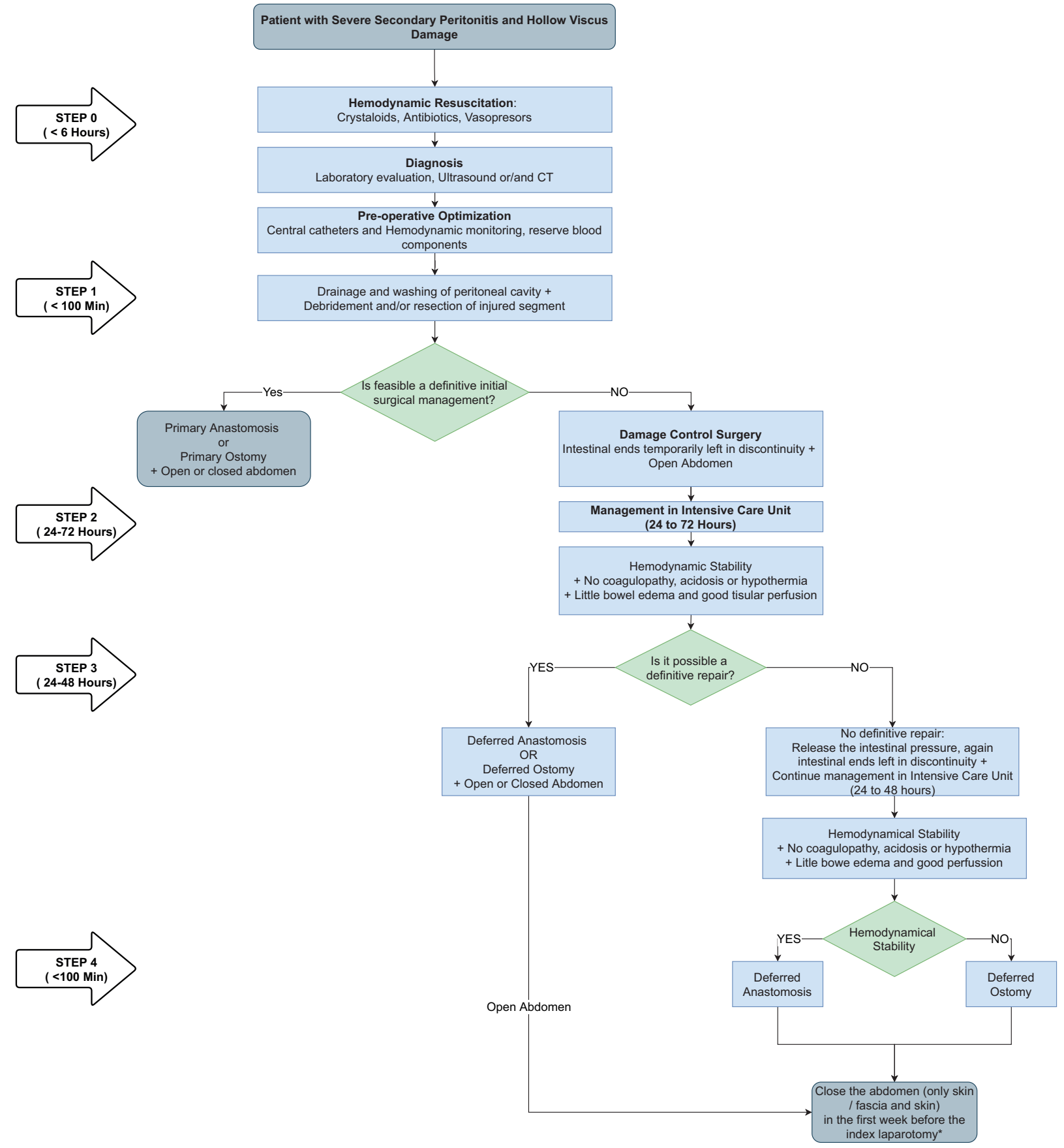

Figure 1. Algorithm for the management of non-traumatic abdominal pathology applying the damage control surgery principles.

damage control surgery was deferred anastomosis. Therefore, we propose the following algorithm that includes the principles of damage control surgery and deferred anastomosis as the main surgical strategy for intestinal reconstruction: (Figure 1).

Phase 0: Crystalloid resuscitation and broad-spectrum antibiotics must be initiated associated with vasopressors if necessary. Diagnosis must be made by laboratory results and/or diagnostic tools. Preparation for surgery should begin with central catheter placement, invasive monitoring and blood components reserve. 
Phase I: Drainage and lavage of the peritoneal cavity, with debridement and intestinal resection of the injured segment should be performed. If primary anastomosis is feasible, it should be performed, and the abdomen can be left opened or closed. Otherwise, if the anastomosis is not possible due to edema, hypoperfusion or hemodynamic instability, the surgeon should consider an ostomy with or without definite abdominal wall closure. However, Damage Control Surgery can be applied by leaving the bowel in discontinuity with a temporary ligation at the proximal and distal ends with an umbilical band or linear stapler with deferred closure of the abdomen by positioning a negative pressure dressing.

Phase II: The patient must be transferred to the Intensive Care Unit with hemodynamic support. Acidosis, hypothermia, and coagulopathy should be corrected. This phase should normally last between 24 and 48 hours, with a maximum of 72 hours.

Phase III: A second surgical approach must be made. If the coagulopathy, acidosis, hypothermia and intestinal edema resolve and adequate tissue perfusion is observed a handsewn or mechanical deferred anastomosis should be performed. If the patient does not meet these criteria and the surgeon considers that there is no other option, he or she may decide to perform definitive management with an ostomy. However, there may be a third scenario in which the intestinal ligatures could be released, the intestinal contents emptied, the bowel is left in discontinuity, a negative pressure dressing should be place and the patient should be transferred to the Intensive Care Unit for another 24 to 48 hours.

Phase IV: The clinical condition of the patient should be evaluated, and the definitive repair technique should be decided. If the clinical condition is favorable, a primary anastomosis must be preferred. Otherwise, an ostomy must be performed. In all cases, abdominal wall closure must be performed in the first seven days, either skin closure or skin and fascial closure. Moreover, abdominal wall reconstruction can be intended 8-12 months after closure.

\section{Conclusion}

The principles of damage control surgery can be applied in non-traumatic abdominal pathologies. This strategy is feasible and safe without increasing mortality or morbidity. Damage control is a light amid the storm for patients with metabolic decompensation due to abdominal sepsis or massive hemorrhage. It translates into a time window for a deferred intestinal reconstruction by anastomosis with better short- and long-term results.

\section{References}

1. Roberts DJ, Ball CG, Feliciano D V., Moore EE, Ivatury RR, Lucas CE, et al. History of the innovation of damage control for management of trauma patients: 1902-2016. Ann Surg. 2017; 265:1034-44. Doi: 10.1097/ SLA.0000000000001803.

2. Coccolini F, Roberts D, Ansaloni L, Ivatury R, Gamberini E, Kluger Y, et al. The open abdomen in trauma and non-trauma patients: WSES guidelines. World J Emerg Surg. 2018;13:7. Doi: 10.1186/s13017-018-0167-4.

3. Garcia A, Martinez J, Rodriguez J, Millan M, Valderrama G, Ordoñez C, et al. Damage-control techniques in the management of severe lung trauma. J Trauma Acute Care Surg. 2015;78:45-50. Doi: 10.1097/ TA.0000000000000482.

4. Khan A, Hsee L, Mathur S, Civil I. Damage-control laparotomy in nontrauma patients. J Trauma Acute Care Surg. 2013;75:365-8. Doi: 10.1097/TA.0b013e31829cb65e.

5. Girard E, Abba J, Boussat B, Trilling B, Mancini A. Damage control surgery for non-traumatic abdominal emergencies. World J Surg. 2018; 42(4): 965-973. Doi: 10.1007/s00268-017-4262-6.

6. Godat L, Kobayashi L, Costantini T, Coimbra R. Abdominal damage control surgery and reconstruction: 
7. Stone HH, Lamb JM. Use of pedicled omentum as an autogenous pack for control of hemorrhage in major injuries of the liver. Surg Gynecol Obstet .1975;141:92-4.

8. Feliciano D V., Mattox KL, Jordan GL, Burch JM, Bitondo CG, Cruse PA. Management of 1000 consecutive cases of hepatic trauma (1979-1984). Ann Surg. 1986; 204:438-45. Doi: 10.1097/00000658-198610000-00012.

9. Feliciano D V., Burch JM, Spjut-Patrinely V, Mattox KL, Jordan GL. Abdominal gunshot wounds. An urban trauma center\&apos;s experience with 300 consecutive patients. Ann Surg. 1988;208:362-70. Doi: 10.1097/00000658$198809000-00014$.

10. Burch JM, Ortiz VB, Richardson RJ, Martin RR, Mattox KL, Jordan GL. Abbreviated laparotomy and planned reoperation for critically injured patients. Ann Surg. 1992; 215: 476-84. Doi: 10.1097/00000658-199205000-00010.

11. Rotondo MF, Schwab CW, McGonigal MD, Phillips GR, Fruchterman TM, Kauder DR, et al. "Damage control": an approach for improved survival in exsanguinating penetrating abdominal injury. J Trauma. 1993;35:375-82.

12. Chovanes J, Cannon JW, Nunez TC. The evolution of damage control surgery. Surg Clin North Am. 2012;92:85975. Doi: 10.1016/j.suc.2012.04.002.

13. Quyn AJ, Johnston C, Hall D, Chambers A, Arapova N, Ogston S, et al. The open abdomen and temporary abdominal closure systems - historical evolution and systematic review. Colorectal Dis. 2012; 14(8): e429-38. Doi: 10.1111/j.1463-1318.2012.03045.x.

14. Wall MJ, Villavicencio RT, Miller CC, Aucar JA, Granchi TA, Liscum KR, et al. Pulmonary tractotomy as an abbreviated thoracotomy technique. J Trauma. 1998; 45: 1015-23. Doi: 10.1097/00005373-199812000-00008.

15. Offner PJ, De Souza AL, Moore EE, Biffl WL, Franciose RJ, Johnson JL, et al. Avoidance of abdominal compartment syndrome in damage-control laparotomy after trauma. Arch Surg. 2001; 136:676-80. Doi: 10.1001/ archsurg.136.6.676.

16. Rogers WK, Garcia L. Intraabdominal hypertension, abdominal compartment syndrome, and the open abdomen. Chest. 2018;153:238-50. Doi: 10.1016/j.chest.2017.07.023.

17. Kirkpatrick AW, Roberts DJ, De Waele J, Jaeschke R, Malbrain MLNG, De Keulenaer B, et al. Intra-abdominal hypertension and the abdominal compartment syndrome: Updated consensus definitions and clinical practice guidelines from the World Society of the Abdominal Compartment Syndrome. Intensive Care Med. 2013; 39(7):1190206. Doi: 10.1007/s00134-013-2906-z.

18. Holcomb JB. Damage control resuscitation. J Trauma. 2007; 62(6 Suppl):S36-7. Doi: 10.1097/ TA.0b013e3180654134.

19. Holcomb JB, Jenkins D, Rhee P, Johannigman J, Mahoney P, Mehta S, et al. Damage control resuscitation: Directly addressing the early coagulopathy of trauma. J Trauma. 2007; 62: 307-10. Doi: 10.1097/TA.0b013e3180324124.

20. Ordoñez CA, Parra MW, Serna JJ, Rodríguez H F, García AF, Salcedo A, et al. Damage Control Resuscitation : REBOA as the new fourth pillar. Colomb Med (Cali). 2020; 51(4):e4014353. Doi: 10.25100/cm.v51i4.4353.

21. Hörer TM, Pirouzram A, Khan M, Brenner M, Cotton B, Duchesne J, et al. Endovascular resuscitation and trauma management (EVTM) - practical aspects and implementation. SHOCK. 2020. Doi: 10.1097/shk.0000000000001529.

22. Weber DG, Bendinelli C, Balogh ZJ. Damage control surgery for abdominal emergencies. Br J Surg. 2014;101:e109-18. Doi: 10.1002/bjs.9360.

23. Rhodes A, Evans LE, Alhazzani W, Levy MM, Antonelli M, Ferrer R, et al. Surviving sepsis campaign: international guidelines for management of sepsis and septic shock: 2016. Intensive Care Med. 2017;43:304-77. Doi: 10.1007/ s00134-017-4683-6. 
24. Finlay IG, Edwards TJ, Lambert AW. Damage control laparotomy. Br J Surg. 2004; 91: 83-5. Doi: 10.1002/ bjs. 4434 .

25. Perathoner A, Klaus A, Mühlmann G, Oberwalder M, Margreiter R, Kafka-Ritsch R. Damage control with abdominal vacuum therapy (VAC) to manage perforated diverticulitis with advanced generalized peritonitis-a proof of concept. Int J Colorectal Dis. 2010;25:767-74. Doi: 10.1007/s00384-010-0887-8.

26. Kafka-Ritsch R, Birkfellner F, Perathoner A, Raab H, Nehoda H, Pratschke J, et al. Damage control surgery with abdominal vacuum and delayed bowel reconstruction in patients with perforated diverticulitis hinchey III/IV. J Gastrointest Surg. 2012;16:1915-22. Doi: 10.1007/s11605-012-1977-4.

27. Sohn M, lesalnieks I, Agha A, Steiner P, Hochrein A, Pratschke J, et al. Perforated diverticulitis with generalized peritonitis: low stoma rate using a "damage control strategy". World J Surg. 2018;42:3189-95. Doi: 10.1007/s00268-018-4585-y.

28. Tartaglia D, Costa G, Camillò A, Castriconi M, Andreano M, Lanza M, et al. Damage control surgery for perforated diverticulitis with diffuse peritonitis: saves lives and reduces ostomy. World J Emerg Surg. 2019;14:19. Doi: 10.1186/s13017-019-0238-1.

29. Person B, Dorfman T, Bahouth H, Osman A, Assalia A, Kluger Y. Abbreviated emergency laparotomy in the non-trauma setting. World J Emerg Surg. 2009;4: 41. Doi: 10.1186/1749-7922-4-41.

30. Subramanian A, Balentine C, Palacio CH, Sansgiry S, Berger DH, Awad SS. Outcomes of damage-control celiotomy in elderly nontrauma patients with intra-abdominal catastrophes. Am J Surg. 2010;200:783-9. Doi: 10.1016/j.amjsurg.2010.07.027.

31. Khan A, Hsee L, Mathur S, Civil I. Damage-control laparotomy in nontrauma patients: review of indications and outcomes. J Trauma Acute Care Surg. 2013;75:365-8. Doi: 10.1097/TA.0b013e31829cb65e.

32. Tamijmarane A, Ahmed I, Bhati CS, Mirza DF, Mayer AD, Buckels JAC, et al. Role of completion pancreatectomy as a damage control option for post-pancreatic surgical complications. Dig Surg. 2006;23:22934. Doi: $10.1159 / 000095395$.

33. Ordoñez CA, Puyana JC. Management of peritonitis in the critically ill patient. Surg Clin North Am. 2006;86:1323-49. Doi: 10.1016/j.suc.2006.09.006.

34. Ordóñez CA, Pineda JA, Arias RH, Benítez FA, Toro LE, Aristizábal G, et al. Curso clínico de la peritonitis grave en pacientes críticamente enfermos tratados con sutura primaria diferida. Rev Colomb Cirugía. 2008;23:22-30.

35. Sharpe JP, Magnotti LJ, Fabian TC, Croce MA. Evolution of the operative management of colon trauma. Trauma Surg Acute Care Open. 2017;2:e000092. Doi: 10.1136/tsaco-2017-000092.

36. Ordóñez CA, Sánchez Ál, Pineda JA, Badiel M, Mesa R, Cardona U, et al. Deferred primary anastomosis versus diversion in patients with severe secondary peritonitis managed with staged laparotomies. World J Surg. 2010;34:169-76. Doi: 10.1007/s00268-009-0285-y.

37. Ordoñez CA, Parra M, García A, Rodríguez F, Caicedo Y, Serna JJ, et al. Damage control surgery may be a safe option for severe non-trauma peritonitis management: proposal of a new decision-making algorithm. World J Surg. 2021;45:1043-52. Doi: 10.1007/s00268-020-05854-y. 